\title{
THE COUNTRY OF ORIGIN AS A FACTOR IN PRODUCT QUALITY PERCEPTION
}

\section{ZEMLJA PODRIJETLA KAO ODREDNICA PERCEPCIJE KVALITETE PROIZVODA}

\begin{abstract}
The main purpose of this paper is to investigate the importance of the country of origin (COO) on the product quality perception, depending on the product's $\mathrm{COO}$ development level and the $\mathrm{COO}$ of the consumer. 222 respondents from Germany and Croatia (consumers' COO - developed and developing country) participated in the survey on the quality of products originating from Belgium and Romania (products' COO - developed and developing country) for 3 different product categories (high, medium, and low level of purchasing risk). The results show that the product's $\mathrm{COO}$ is an important factor in the product quality perception and that there are differences in the perception of product quality depending on the product's $\mathrm{COO}$ development level in cases of all levels of purchasing risk. However, product quality is a subjective category that depends on consumer's perceptions and changes depending on the momentum at the market, so it is important to keep exploring this area for a better understanding of consumers' attitudes and perceptions.
\end{abstract}

KEY WORDS: country of origin, product quality, product category, purchase risk

SAŽETAK: Osnovna svrha ovog rada jest istražiti važnost zemlje podrijetla u percepciji kvalitete proizvoda ovisno o stupnju razvijenosti zemlje podrijetla proizvoda i zemlje podrijetla potrošača. Istraživanje je provedeno na 222 ispitanika iz Njemačke i Hrvatske (zemlja podrijetla potrošača - razvijena i zemlja u razvoju) o kvaliteti proizvoda koji su podrijetlom iz Belgije i Rumunjske (zemlja podrijetla proizvoda - razvijena i zemlja u razvoju) za 3 različite kategorije proizvoda (visoka, srednja i niska razina kupovnog rizika). Rezultati pokazuju da je zemlja podrijetla proizvoda važna determinanta u percepciji kvalitete proizvoda te da postoje razlike u percepciji kvalitete proizvoda ovisno o stupnju

Zoran Krupka, Ph. D., Associate Professor, Department of Marketing, Faculty of Economics \& Business, University of Zagreb, Trg J. F. Kennedyja 6, 10000 Zagreb, Croatia, e-mail: zkrupka@efzg.hr

** $\quad$ Mateja Malogorski, mag. oec., Trnsko 9c, 10000 Zagreb, Hrvatska 
razvijenosti zemlje podrijetla proizvoda u slučaju svih razina kupovnog rizika. Međutim, kvaliteta proizvoda je subjektivna kategorija koja ovisi o percepciji potrošača te se mijenja ovisno o trenovima na tržištu, stoga je neophodno nastaviti istraživati ovo područje kako bi se bolje razumjeli stavovi i percepcije potrošača.

KLJUČNE RIJEČI: zemlja podrijetla, kvaliteta proizvoda, kategorija proizvoda, kupovni rizik

\section{INTRODUCTION}

In the last three decades, marketing professionals have become aware of the importance and impact that the country of origin $(\mathrm{COO})$ and its image have on product quality perception and consumer purchasing decisions (Agyekum, Haifeng and Agyeiwaa, 2015; Anastasiei and Chiosa, 2014; Chao, 1998; Milovan, Ardelean, Sahour and Jurca, 2019). Numerous studies (Agyekum et al., 2015; Anastasiei and Chiosa, 2014; Schaefer, 1995) have shown that attitudes, associations, and stereotypes that one has about a certain country directly affect his/her perception of products' quality coming from it. Differences in product quality perceptions are particularly visible between products coming from developed countries and products coming from transitional and developing countries (Apetrei, 2010). Like most research, the one conducted by Roth and Diamantopoulos (2009) has shown that consumers have more positive attitudes regarding quality for products coming from developed countries than for those coming from transitional and developing countries. Also, it has been observed that the importance and impact of $\mathrm{COO}$ on product quality perception and consumer purchasing decisions differ depending on the level of product's purchasing risk (Chattalas, Kramer and Takada, 2008; Parameswaran and Yaprak, 1987).

Most of the papers about COO still rely on research conducted in developed countries like the USA, Japan, Germany, Sweden and UK. However, due to the process of globalization, economic growth and rapid growth of population, transitional and developing countries, like China, India, Brazil, Nigeria, Poland etc., are becoming more and more important, and more focus in COO research should be on those countries (Clifton, 2014). Additionally, findings of $\mathrm{COO}$ influence on consumers in transitional and developing countries are inconsistent (Sharma, 2011), and some authors state that it is not clear whether $\mathrm{COO}$ effects are the same for consumers in developed, and those coming from transitional and developing countries (Ahmed \& d'Astous, 2004; Touzani, Fatma \& Meriem, 2015).

Based on the beforementioned, the purpose of this paper is to explore the importance of the $\mathrm{COO}$ on the product quality perception depending on the product's $\mathrm{COO}$ level of development and product's level of purchasing risk, observing differences in attitudes of respondents depending on their COO. More precisely, with this paper we will try to fill the gap in the existing literature by comparing the attitudes of respondents from transitional and developed countries (consumers $\mathrm{COO}$ ) what was lacking in previous research. Also, it will be observed the importance of the product's $\mathrm{COO}$ in perceiving quality for three product categories with different purchasing risks, again comparing attitudes of the respondents regarding the level of their $\mathrm{COO}$. The introduction is followed by a literature review presenting current knowledge about $\mathrm{COO}$ and explaining the hypotheses background. After that, research methodology is described and research results are presented, which is fol- 
lowed by a discussion. At the end of the paper, the main conclusions, the research limitations, and recommendations for future research are presented.

\section{LITERATURE REVIEW}

Many authors (Chinen, Jun and Hampton, 2000; Ramsaran and Wibowo, 2016; Roth \& Romeo, 1992; Samli, 1995; Schooler, 1965) have focused their research on studying the COO concept and its impact on consumer behavior. Schooler (1965) and Nagashima (1970) were the first to find that $\mathrm{COO}$ influences consumer buying behavior. According to Nagashima (1970), COO is an image, reputation, and stereotypes that business people and consumers associate with products from a particular country. Very similarly, Roth and Romeo (1992) define COO as the overall perception consumers have of products from a particular country, while Papadopoulos and Heslop (1993) explain the COO effect as the process by which the origin of an imported product affects the way consumers perceive the product and value its attributes. In accordance with the foregoing, the product's COO represents the key information that influences consumer's perception, product evaluation, and his/her willingness to accept and purchase foreign products (Samli, 1995).

Product quality can be defined as product superiority and excellence (Bilkey and Nes, 1982). It is a highly subjective category and is very difficult to assess, which is why consumers use various factors in the assessment process. Factors that help consumers in evaluating product quality are price, brand, store appearance, market share, warranty, but also COO (Bearden and Shimp, 1982; Kalicharan, 2014).

The influence of the $\mathrm{COO}$ as an extrinsic factor in the evaluation of product quality depends on product category, level of purchasing risk, product's $\mathrm{COO}$ development level, but also consumer's COO level of development (Anić, 2010; Brouthers, 2000; Chao, 1998; Cordell, 1991; Verlegh, Stennkamp and Meulenberg, 1999). Beliefs that developed countries produce better quality products are based on the image that such countries have in the minds of consumers (Magier-Lakomi and Boguszewicz-Kreft, 2015). Beliefs that COO development level affects the perception of product quality was confirmed by research conducted by Katsanis and Thakor (1997) for products originated from Germany and South Korea (consumers believe that products which are produced in Germany, economically more developed and politically stable country, are of higher quality). Cordell (1991), as well as Katsanis and Thakor (1997), concluded that consumers perceive products whose COO is a transitional and/or developing country as products of poorer quality, design and workmanship, compared to products whose $\mathrm{COO}$ is a developed country.

COO's level of economic development affects not only how foreign consumers perceive product quality coming from it, but also affects its consumers and their perception of products coming from other (developed and developing) countries. According to a study by Udine, Parvin and Rahman (2013), consumers from transitional and/or developing countries rate products from developed countries as better in comparison with similar products from less developed countries. On that topic, Chun (1992) surveyed consumers from South Korea (then a developing country) who rated foreign products as better than domestic ones.

Ethnocentrism (predominantly for consumers from developed countries) and materialism (predominantly for consumers from transitional and developing countries) are cited 
as two main factors determining consumer behavior related to the $\mathrm{COO}$ and indirectly to product quality assessment (Brandao and Duraes, 2018). The reason for this is that consumers from developed countries believe that their products are better by the fact that their countries are more developed, while consumers from less developed countries tend to buy more expensive foreign products (whose $\mathrm{COO}$ is a developed country) to achieve self-realization in society by consuming such products. Also, some research has shown that consumers from transitional and developing countries consider products from other developing countries to be of poor quality (Amine and Shin, 2002; Huddleston, Good and Stoel, 2001). However, the inconsistency in findings of $\mathrm{COO}$ influence on consumers in transitional and developing countries (Sharma, 2011), with a lack of papers comparing the attitudes of respondents coming from developed and transition or developing countries, motivated us to set the first hypothesis:

$\mathrm{H} 1: \mathrm{COO}$ of the product is a more important factor in the perception of product quality for respondents from the developed country than for respondents from a transitional or developing country.

In assessing product quality, consumers are influenced by intrinsic (e.g., preferences, attitudes, knowledge, etc.) and extrinsic (e.g., price, brand, COO, etc.) factors (Chao, 1998; Kalicharan, 2014; Urbonavičius, Dikčius and Navickaite, 2011). Which factor will be more important and which will have a greater impact on the consumer, depends on the product category and the level of purchasing risk. Bruwer, Fong and Saliba (2013) define perceived purchasing risk as the uncertainty that consumers face when they cannot foresee the consequences of their purchase decisions. There are different types of purchasing risk: financial, functional, physical, suitability, social and psychological; and which one will prevail depends on the purchase intention and situation.

Depending on whether it is a product whose purchase poses a high, medium, or low risk, consumers seek more or less information that could help them in product quality assessment and in decreasing uncertainty of purchasing decision (Dowling and Staelin, 1994). In the case of high-risk products, extrinsic factors like the brand, its price and $\mathrm{COO}$ become very important because consumers cannot make a purchasing decision based solely on the intrinsic factors (Ahmed et al., 2004; Diamantopoulos, Schlegelmilch and Palihawadana, 2011). In such situations, for example, when buying a car whose purchase is characterized by a high level of risk, brand, price, warranty and $\mathrm{COO}$ become important factors by which consumers will assess the quality of that car and make a purchase decision (Liefled, 1993; Piron, 2000).

As the level of purchasing risk decreases, consumers increasingly rely on internal factors, i.e. the knowledge and experience, which provide a sufficient basis for assessing product quality and making a purchasing decision. Of course, the same product does not have the same level of purchasing risk for all consumers. What is a high purchasing risk product for one consumer may be a medium purchasing risk product for another. It depends on the consumer's knowledge, interest, personality, the reason for the purchase, but also the available finances of the consumer. For products with a medium level of purchasing risk, consumers seek confirmation of their decision and knowledge through external factors such as COO (Alden, Hoyer and Crowley, 1993).

Unlike high- or medium-risk products, low-risk products are rarely evaluated rigorously before purchase (Alden et al., 1993). For most low-risk purchases, consumers tend to 
rely on a few salient factors (e.g., brand name) that activate generalizations from memory about the product quality and brand reputation. These evaluation processes differ from the more deliberate, multi-attribute approaches associated with higher-risk products (Agrawal and Teas, 2000).

The information of the $\mathrm{COO}$ became an important factor in product quality evaluation and purchasing decisions of customers many years ago (Biswas and Chowdhury, 2011). Studies have shown that COO affects the customers in a number of ways and can influence their purchasing intentions (Sohail, 2005; Parvin, Rahman and Uddin, 2013; Kim, 2008), but remain important to find out how COO influence perception on product quality depending of the level of purchasing risk. Based on that, the following hypotheses have been set:

$\mathrm{H} 2$ : For high-level purchasing risk products, perceived quality is higher if the product's $\mathrm{COO}$ is a developed country compared to products whose $\mathrm{COO}$ is transitional or developing countries.

H3: For medium-level purchasing risk products, perceived quality is higher if the product's $\mathrm{COO}$ is a developed country compared to products whose $\mathrm{COO}$ is transitional or developing countries.

H4: For low-level purchasing risk products, there is no difference in perceived quality depending on the product's $\mathrm{COO}$ development level (developed, transitional or developing country).

\section{RESEARCH}

\subsection{Research methodology and sample}

For the purposes of this paper, research was conducted using a highly structured questionnaire on a sample of 222 respondents from the Republic of Croatia $(n=121)$ and the Republic of Germany $(n=101)$. Croatia and Germany were chosen as the context for the research because they represent countries with different levels of development - Croatia as a transitional and Germany as a developed country. Accordingly, the collected data could also be analyzed depending on consumers' COO. Sample characteristics are shown in Table 1.

The questionnaire consisted of three parts - the first part was related to the demographic characteristics of the respondents, the second part was related to the $\mathrm{COO}$ importance in purchase decisions (12 questions), while the questions (total of 25) of the third part of the questionnaire were about three product categories (laptop, bed, and honey) with different levels of purchasing risk coming from developed (Belgium) and developing (Romania) countries.

Scales were formed based on previous research of COO's influence on consumer behavior and product quality assessment by Dholakia, Zhao and Duan (2020), Sharma (2019), Cakici and Shukla (2017), Josiassen and Assaf (2010), Garvin (1987), and Parameswaran and Yaprak (1986). The questionnaire was distributed in Croatian and German languages using the back-to-back translation method. 
Table 1: Characteristics of the respondents

\begin{tabular}{|c|c|c|c|c|}
\hline & \multicolumn{2}{|c|}{ Croatia } & \multicolumn{2}{|c|}{ Germany } \\
\hline Total number & 121 & $100 \%$ & 101 & $100 \%$ \\
\hline \multicolumn{5}{|l|}{\begin{tabular}{|l|} 
Gender \\
\end{tabular}} \\
\hline Male & 29 & $23,9 \%$ & 38 & $37,6 \%$ \\
\hline Female & 92 & $76,1 \%$ & 63 & $62,4 \%$ \\
\hline \multicolumn{5}{|l|}{ Age } \\
\hline $18-22$ & 41 & $33,1 \%$ & 7 & $6,4 \%$ \\
\hline $23-27$ & 63 & 50,85 & 62 & $56,4 \%$ \\
\hline $28-35$ & 17 & $13,7 \%$ & 32 & $29,1 \%$ \\
\hline $36-45$ & 2 & $1,6 \%$ & 5 & $4,5 \%$ \\
\hline \multicolumn{5}{|l|}{\begin{tabular}{|l|} 
Education \\
\end{tabular}} \\
\hline Primary-school & 0 & $0 \%$ & 0 & $0 \%$ \\
\hline High-school & 35 & $28,9 \%$ & 61 & $60,4 \%$ \\
\hline Bachelor degree & 64 & $52,9 \%$ & 32 & $31,7 \%$ \\
\hline Master degree & 21 & $17,4 \%$ & 8 & $7,9 \%$ \\
\hline Ph.D. & 1 & $0,8 \%$ & 0 & $0 \%$ \\
\hline \multicolumn{5}{|l|}{ Employment } \\
\hline Student & 89 & $73,5 \%$ & 61 & $60,4 \%$ \\
\hline Employed & 32 & $26,5 \%$ & 36 & $35,6 \%$ \\
\hline Unemployed & 0 & $0 \%$ & 1 & $0,9 \%$ \\
\hline Retired & 0 & $0 \%$ & 0 & $0 \%$ \\
\hline \multicolumn{5}{|l|}{ Income } \\
\hline $0-100$ EUR & 20 & $16,5 \%$ & 6 & $5,9 \%$ \\
\hline 101-250 EUR & 42 & $34,7 \%$ & 4 & $4 \%$ \\
\hline 251-500 EUR & 18 & $14,9 \%$ & 33 & $32,7 \%$ \\
\hline 501-1.000 EUR & 33 & $27,3 \%$ & 20 & $19,8 \%$ \\
\hline 1.001-1.500 EUR & 4 & $3,3 \%$ & 12 & $11,9 \%$ \\
\hline More than 1.500 EUR & 4 & $3,3 \%$ & 26 & $25,7 \%$ \\
\hline
\end{tabular}

\subsection{Research results}

To test Hypothesis 1 (COO of the product is a more important factor in the perception of product quality for respondents from the developed country than for respondents from a transitional or developing country), statements S1, S2, S3 and S4 were used (Table 2). Respondents should express their level of agreement using the Likert scale from 1 (I completely disagree) to 7 (I completely agree).

The mean value of the responses for S1 for Croatian respondents was 3.98, and for German 5.17. According to the data, it can be concluded that the German respondents agreed with S1 while the Croatian respondents neither agree nor disagree with it. Furthermore, respondents were required to express a degree of agreement with the statement "Country of origin affects product quality" (S2). The mean value of the answers of Croatian respondents was 4.83 , and German 4.74, which indicates a statistically significant shift in a positive direction for respondents from both countries. For S3 ("Products from developed countries are of better quality than products from transitional and developing countries."), 
the mean value of the answers of Croatian respondents is 4.44 (statistically significant shift in the positive direction), and German 3.61 (statistically significant shift in the negative direction). The results suggest that Croatian respondents believe that products coming from developed countries are of higher quality than products coming from transitional and developing countries, while respondents from Germany do not agree with that statement. Finally, for S4 the mean value of the answers of Croatian respondents is 4.13, and German 3.94. The results suggest that Croatian respondents believe that products coming from developed countries are longer lasting, and thus better than products coming from transitional and developing countries, while respondents from Germany do not have a strong opinion about this statement (they do not agree nor disagree with it).

Table 2: Importance of country of origin in product quality perception

\begin{tabular}{|c|c|c|c|}
\hline & Croatia & Germany & t-test \\
\hline $\begin{array}{l}\text { S1: When buying a product, its country of origin } \\
\text { is important to me. }\end{array}$ & m.v. $=3,98$ & $\mathrm{~m} . \mathrm{v} .=\mathbf{5 , 1 7}$ & $t=-4,83, p=.00$ \\
\hline S2: Country of origin affects product quality. & m.v. $=\mathbf{4 , 8 3}$ & m.v. $=4,74$ & $t=0,37, p=.35$ \\
\hline $\begin{array}{l}\text { S3: Products from developed countries are of } \\
\text { better quality than products from transitional } \\
\text { and developing countries. }\end{array}$ & m.v. $=4,44$ & m.v. $=3,61$ & $t=3,14, p=.00$ \\
\hline $\begin{array}{l}\text { S4: Products from developed countries are longer } \\
\text { lasting than products from transitional and } \\
\text { developing countries. }\end{array}$ & m.v. $=4,13$ & m.v. $=3,94$ & $t=0,73, p=.23$ \\
\hline $\begin{array}{l}\text { S5: The product's country of origin does not } \\
\text { necessarily have to be the country of assembly of } \\
\text { the product. }\end{array}$ & $\mathrm{m} . \mathrm{v} .=4,88$ & $\mathrm{~m} . \mathrm{v} .=4,77$ & $t=0,39, p=.35$ \\
\hline $\begin{array}{l}\text { S6: When buying an expensive product, its country } \\
\text { of origin is important to me. }\end{array}$ & $\mathrm{m} . \mathrm{v} .=4,50$ & $\mathrm{~m} . \mathrm{v} .=4,71$ & $t=0,74, p=.23$ \\
\hline $\begin{array}{l}\text { S7: When buying an expensive product, high quality } \\
\text { is important to me. }\end{array}$ & m.v. $=6,20$ & m.v. $=5,94$ & $t=1,16, p=.12$ \\
\hline $\begin{array}{l}\text { S8: When buying an expensive product, the price is } \\
\text { more important to me than the product's country of } \\
\text { origin. }\end{array}$ & $\mathrm{m} . \mathrm{v} .=4,83$ & $\mathrm{~m} . \mathrm{v} .=5,14$ & $t=-1,25, p=.11$ \\
\hline $\begin{array}{l}\text { S9: When buying a cheap product, I don't look at its } \\
\text { country of origin. }\end{array}$ & m.v. $=4,55$ & m.v. $=4,59$ & $t=-0,15, p=.44$ \\
\hline $\begin{array}{l}\text { S10: When buying a cheap product, the high quality } \\
\text { of the product is not important to me. }\end{array}$ & m.v. $=3,82$ & m.v. $=3,64$ & $t=0,70, p=.24$ \\
\hline $\begin{array}{l}\text { S11: When buying high-risk products, I look at the } \\
\text { country of origin of the product. }\end{array}$ & $\mathrm{m} . \mathrm{v} .=4,93$ & $m . v .=5,50$ & $t=2,30, p=.01$ \\
\hline $\begin{array}{l}\text { S12: When buying low-risk products, I do not look } \\
\text { at the country of origin of the product. }\end{array}$ & m.v. $=3,99$ & $\mathrm{~m} . \mathrm{v} .=3,90$ & $t=0,37, p=.36$ \\
\hline
\end{tabular}

A statistically significant difference in the attitudes of respondents from Croatia and Germany exists only in two (S1 and S3) of the four statements and hypothesis H1 cannot be accept- 
ed. If we look at the results for the remaining statements (S5-S12) that can be indirectly related to the first hypothesis, for 7 out of 8 statements there is no statistically significant differences between responses of Croatian and German respondents, which further supports the conclusion that $\mathrm{H} 1$ cannot be accepted. Furthermore, Consumers in developed and developing countries perceive differently importance of country of origin $(\mathrm{S} 1 ; \mathrm{p}=, 000)$, however only when buying high-risk products ( $\mathrm{S} 11 ; \mathrm{p}=, 01)$, where consumers from developed countries value $\mathrm{COO}$ even more than do the consumers from developing countries, and not when buying low-risk products $(\mathrm{S} 12 ; \mathrm{p}=, 36)$. Consumers from developed and developing countries equally value $\mathrm{COO}$ regardless of product price and product durability. Therefore, $\mathrm{COO}$ cannot be considered to play significantly different role for consumers in developing and developed countries.

To test the second hypothesis (For high-level purchasing risk products, perceived quality is higher if the product's $\mathrm{COO}$ is a developed country compared to products whose $\mathrm{COO}$ is transitional or developing countries), statements shown in Table 3 were used. Respondents were asked to express their level of agreement with the statements using the Likert scale from 1 (I completely disagree) to 7 (I completely agree).

Table 3: COO importance in determining the quality of high-level purchasing risk products

\begin{tabular}{|c|c|c|c|}
\hline Laptop from... & BELGIUM & ROMANIA & t-test \\
\hline S13: ... has quality performance. & m.v. $=4,56$ & m.v. $=3,53$ & $t=6,61, p=.00$ \\
\hline S14: ... has a good / modern design. & m.v. $=4,83$ & m.v. $=3,68$ & $t=7,05, p=.00$ \\
\hline S15: ... is made of quality materials. & m.v. $=4,79$ & m.v. $=3.59$ & $t=7,70, p=.00$ \\
\hline S16: ... is extremely functional. & m.v. $=4,76$ & m.v. $=3,69$ & $t=6,57, p=.00$ \\
\hline S17: ... is long lasting. & m.v. $=4,71$ & m.v. $=3,56$ & $t=7,29, p=.00$ \\
\hline S18: ... has reliable quality. & m.v. $=4,82$ & m.v. $=3,53$ & $t=8,05, p=.00$ \\
\hline $\begin{array}{l}\text { S19: ... is not expensive to maintain / } \\
\text { repair. }\end{array}$ & m.v. & m.v. $=4,08$ & $t=-0,53, p=.30$ \\
\hline S20: ... has a good value for money ratio. & m.v. $=4,53$ & m.v. $=4,10$ & $t=2,61, p=.00$ \\
\hline S21: ... is of good quality. & m.v. $=4,95$ & m.v. $=3,79$ & $t=7,67, p=.00$ \\
\hline
\end{tabular}

For research purposes, the laptop was used as an example of a high-level purchasing risk product. Respondents agreed/have a positive attitude with 8 out of 9 statements related to a laptop from Belgium (only for the statement that a laptop from Belgium is not expensive to maintain/repair they have neither positive nor negative opinion). On the other hand, for a laptop originating from Romania, respondents only agreed with the statement that this laptop has a good value for money ratio (they do not agree with the other statements or do not have a strong opinion about them). Also, from the Table 3 can be seen that there is statistically significant difference in the attitudes of the respondents only for the statement S19. Based on the presented results, hypothesis $\mathrm{H} 2$ is accepted.

To test the third hypothesis (For medium-level purchasing risk products, perceived quality is higher if the product's $\mathrm{COO}$ is a developed country compared to products whose $\mathrm{COO}$ is transitional or developing countries) a bed was used as a medium-level purchasing risk product. Table 4 shows the attitudes of the respondents regarding the statements if the bed originates from Belgium or Romania. Again, respondents were required to express the 
level of agreement with the above statements on the Likert scale from 1 (I completely disagree) to 7 (I completely agree).

Table 4: COO importance in determining the quality of medium-level purchasing risk products

\begin{tabular}{|l|l|l|c|}
\cline { 2 - 4 } \multicolumn{1}{l|}{ Bed from... } & BELGIUM & ROMANIA & t-test \\
\hline S22: ...is of good quality. & m.v. $=4,93$ & m.v. $=4,12$ & $t=5,36, p=.00$ \\
\hline S23: ...has a good / modern design. & m.v. $=4,98$ & m.v. $=3,81$ & $t=7,87, p=.00$ \\
\hline S24: ...is long lasting. & m.v. $=5,03$ & m.v. $=4,17$ & $t=5,43, p=.00$ \\
\hline S25: ...has reliable quality. & m.v. $=5,10$ & m.v. $=4,06$ & $t=6,74, p=.00$ \\
\hline S26: ...is made of quality wood or plastic. & m.v. $=5,00$ & m.v. $=4,06$ & $t=6,20, p=.00$ \\
\hline S27: ...has a good value for money ratio. & m.v. $=4,89$ & m.v. $=4,40$ & $t=3,15, p=.00$ \\
\hline $\begin{array}{l}\text { S28: ...is made with a modern production } \\
\text { process. }\end{array}$ & m.v. $=5,18$ & m.v. $=4,09$ & $t=6,95, p=.00$ \\
\hline
\end{tabular}

As can be seen from Table 4, respondents agreed with all 7 statements related to the bed whose $\mathrm{COO}$ is Belgium. On the other hand, the respondents agreed with only 3 out of 7 statements (S22, S24 and S27) referring to the bed originating from Romania, with one statement (S23) they do not agree, while with 3 statements (S25, S26 and S28) they do not agree nor disagree. Also, Table 4 shows that there is a statistically significant difference in the attitudes of the respondents about the quality of the product coming from Belgium compared to the product coming from Romania for each statement. Based on the presented results, hypothesis $\mathrm{H} 3$ is accepted.

To test the last, fourth hypothesis (For low-level purchasing risk products, there is no difference in perceived quality depending on the product's COO development level (developed, transitional or developing country)), respondents were asked to express their level of agreement with the statements shown in Table 5 using the Likert scale from 1 (I completely disagree) to 7 (I completely agree). Honey was used as a low-level purchasing risk product.

Table 5: COO importance in determining the quality of low-level purchasing risk products

\begin{tabular}{|l|c|c|c|}
\hline Honey from... & BELGIUM & ROMANIA & t-test \\
\hline S29: ...is made of quality materials. & m.v. $=4,86$ & m.v. $=4,67$ & $t=1,25, p=.11$ \\
\hline S30: ...has attractive packaging. & m.v. $=5,20$ & m.v. $=4,32$ & $t=6,05, p=.00$ \\
\hline $\begin{array}{l}\text { S31: ...is manufactured with modern } \\
\text { technology. }\end{array}$ & m.v. $=5,24$ & m.v. $=3,97$ & $t=8,24, p=.00$ \\
\hline $\begin{array}{l}\text { S32: ... is made with a modern production } \\
\text { process. }\end{array}$ & m.v. $=5,32$ & m.v. $=4,51$ & $t=5,11, p=.00$ \\
\hline $\begin{array}{l}\text { S33: ...is of high nutritional value } \\
\text { (sweetness, density, energy source). }\end{array}$ & m.v. $=5,06$ & m.v. $=4,62$ & $t=2,88, p=.00$ \\
\hline S34: ...has a characteristic pleasant taste. & m.v. $=5,05$ & m.v. $=4,68$ & $t=2,43, p=.01$ \\
\hline S35: ...has reliable quality. & m.v. $=5,12$ & m.v. $=4,59$ & $t=3,45, p=.00$ \\
\hline S36: ...has a good value for money ratio. & m.v. $=4,86$ & m.v. $=4,82$ & $t=0,23, p=.41$ \\
\hline S37: ...is of good quality. & m.v. $=5,15$ & m.v. $=4,80$ & $t=2,27, p=.01$ \\
\hline
\end{tabular}


Table 5 shows that the respondents agree with all 9 statements concerning honey whose $\mathrm{COO}$ is Belgium. On the other hand, for honey originating in Romania, respondents agree with 8 out of 9 statements (only with S31, respondents do not agree nor disagree). Also, from Table 5 can be seen that for statements "Honey is made of quality materials" and "Honey has a good value for money ratio", there is no statistically significant difference in the attitudes of the respondents whether a honey originating from Belgium or from Romania. For the remaining 7 statements, there is a statistically significant difference in respondents' attitudes between Belgium and Romania as the COO for low-level purchasing risk products. Based on the presented results, hypothesis $\mathrm{H} 4$ cannot be accepted. Although for most statements, respondents have a positive attitude for both COOs, however, for 7 out of 9 statements there is a statistically significant difference in attitudes (more positive attitude in the case of Belgium as $\mathrm{COO}$ ) between the two COOs.

\subsection{Discussion}

Analyzing the results related to the importance of the $\mathrm{COO}$ of the product as a factor for evaluating its quality depending on consumers' / respondents' COO, it can be concluded that there is no statistically significant difference in responses between respondents from developed (Germany) and transitional (Croatia) countries. A more detailed analysis shows that the $\mathrm{COO}$ is important for respondents from Germany (respondents from Croatia do not have a strong attitude) and they are convinced that the $\mathrm{COO}$ affects the quality of products (same as respondents from Croatia). Unlike other research (Magier-Lakomi and Boguszewicz-Kreft, 2015; Uddin, Parvin and Rahman, 2013; Katsanis and Thakor, 1997) which concluded that consumers from developed countries prefer products whose $\mathrm{COO}$ is also developed country and believe that those products are of better quality than products from transitional or developing countries, this research came to a different conclusion. Namely, German respondents do not agree with the statements that products from developed countries are of better quality and longer-lasting. According to these results, when selling products on the German market, one should be aware that for Germans, the COO is an important factor in the purchasing process, but they do not necessarily consider that products coming from less developed countries are of poorer quality. Therefore, it is necessary to investigate the $\mathrm{COO}$ image among German consumers and accordingly emphasize the $\mathrm{COO}$ or country of manufacturing (COM) or country of design (COD), and in case all these options are unfavorable then emphasize the brand and other product characteristics that may influence the purchase decision. On the other hand, in the Croatian market, the COO is not an important factor when buying products, but at the same time, respondents believe that the $\mathrm{COO}$ affects quality and that from more developed countries come higher quality products which is in line with the conclusion of Tigly, Pirtini and Can Erdem (2010) who surveyed Turkish respondents. Therefore, if the product comes from a transitional or developing country, the COO impact on purchasing decision should be mitigated by other factors (such as good price-quality ratio, brand, product availability, etc.) that affect the purchase decision.

Furthermore, this paper investigated the extent to which the product's COO development level is an important factor in assessing the product quality, whether it is a product with a high-, medium- or low-level purchase risk. These data were also analyzed depending on the consumers' / respondents' COO. 
In the case of a product that has a high-level purchasing risk, the product's $\mathrm{COO}$ development level makes a difference in the evaluation or perception of its quality. The results showed that there was a statistically significant difference in the responses between the product which $\mathrm{COO}$ was Belgium with the product which $\mathrm{COO}$ was Romania. Such results can be linked to stereotypes related to Romania as a developing country from which lower-priced and therefore lower-quality products come (Karoui and Khemakhem, 2019). Romanian marketing professionals should place the utmost attention to good value for money ratio when promoting products that are characterized by a high level of purchasing risk, such as in the case of a laptop, and promote ease of maintenance/repair of the product. In addition, in such cases, the strategy should be based on building value, reputation and trust in a brand that is not explicitly linked to the COO. Then the brand becomes a reference point of quality, or the most important extrinsic factor, or at least more important than the COO, in the product quality evaluation. Also, one of the possibilities for companies from developing countries that produce products with high-level purchasing risk, especially technically and technologically sophisticated products, is to move production to a country with a more positive image, in which case they should emphasize COM rather than COO. Additional analysis showed that when consumers' $\mathrm{COO}$ is considered, respondents from developed country had more positive attitudes towards products coming from Belgium compared to respondents from Croatia and had less negative attitudes towards products coming from Romania compared to respondents from Croatia. This is in line with statements S3 and S4 with which respondents from Germany disagree (unlike respondents from Croatia who agree with them) - products coming from more developed countries are of better quality and longer-lasting.

Respondents believe that a medium-level purchasing risk product is of better quality if it comes from a developed country than if it comes from a transitional or developing country. In the case of bed from Belgium, respondents expressed a positive attitude while for the bed from Romania they have a neutral attitude to most statements (only for the statement that bed that is coming from Romania has a good/modern design, respondents have a negative attitude). This is in line with the research conducted by Essoussi and Merunka (2007) which came to conclusion that transitional and developing countries have bad image as COD. With that in mind, companies from developing countries that are producing similar products should work on the design, and one way is to relocate the design to another country and to emphasize the COD instead of the $\mathrm{COO}$ in communication activities. Also, as in the case of products with a high level of purchasing risk, in this case, the marketing strategy should be focused on building a brand that is not explicitly associated with the COO. In addition, one should consider how important design is to consumers for a particular product, and how much other factors (price, value for money, longevity, etc.) are important when making a purchase decision. Again, respondents from Germany rated the product coming from Belgium better than respondents from Croatia, while for a product coming from Romania there are no differences in the attitudes of respondents from Germany and Croatia (except in the case of a design that German respondents think is not good, and respondents from Croatia did not have a strong attitude).

Finally, for a product characterized by a low-level purchasing risk, there are differences in the perceived quality of the product depending on whether it comes from a developed or a developing country. In the context of this research, the respondents agreed with all the 
statements for both - developed and developing - countries products (except for the statement that the product was produced with modern technology in the case of a developing country). As in the case of products with a high level of purchasing risk, it can be said that stereotypes about Romania as a developing country are present when looking at the technological development of the country and the industry. Marketing experts from a developed country, in this case Belgium, should place modern technology and technological processes as a means of differentiating from the competition when promoting products such as honey on foreign markets. On the other hand, when marketing such a product from Romania as a developing country, marketing experts should emphasize that the product is produced from quality materials in a natural and traditional way. In this case, the COO is not something that should be avoided in communication if it is directed towards building the image of a natural, eco-friendly product (El Moussawel and Dekhili, 2018; Banovic, Reinders, Claret, Guerrero and Krystallis, 2019). Of course, the communication strategy, as in the case of the previous examples, depends on the product category. In the case of honey as a product, respondents from Germany have more positive attitudes towards the product from a developed country compared to respondents from Croatia, but they also have more positive attitudes for the product that originating from the transitional country.

At the end, after discussing the results from the managerial perspective, the scientific contribution of the paper is discussed and it is twofold. First, it has been clearly stated (Clifton, 2014; Sharma, 2011) that there is a deficit of COO research in the context of transitional and developing countries, and that conclusions about the impact of the $\mathrm{COO}$ on consumer behavior in those countries are inconsistent (Touzani et al., 2015). This research examines the attitudes of respondents from the developed country and compares them with the attitudes of respondents from the transitional country. Therefore, the analysis is done from the perspective of not only the product's $\mathrm{COO}$, but also the perspective of the $\mathrm{COO}$ of consumers. Previous research has shown that consumers from developed countries believe that better quality and longer-lasting products come from developed countries compared to transitional and developing countries (Ramsaran and Wibowo, 2016), which this research has refuted. Also, previous surveys have been conducted either in a developed or in a developing country, and therefore it was not possible to compare responses depending on consumers' COO. As for this paper, the research was conducted in developed and transitional countries, and a comparison of the results shows that there are no differences in respondents' attitudes about the product's $\mathrm{COO}$ importance as an external factor in assessing product quality. The obtained results, as stated in the discussion from a managerial perspective, show in which direction to adjust the marketing strategy, but also to what extent it is possible to apply the adaptation or standardization of the marketing program.

And secondly, the scientific contribution of this paper is visible in the analysis of research results from the perspective of the perceived purchasing risk level. The literature has found that different products have different levels of purchasing risk (Hamad and Schmitz, 2019), and this paper investigates and analyzes the importance of the product's COO in the perception of its quality depending on the level of purchasing risk. In addition to the discussion above, it is important to note that it is interesting that as purchasing risk decreases, the product's $\mathrm{COO}$ importance in assessing its quality increases in the case of both, developed and developing countries. 


\section{CONCLUSION}

In the last three decades, marketers have become aware of the importance and strength that $\mathrm{COO}$ and its image have on the perception of product quality and consumer purchasing decisions. When consumers cannot independently evaluate the quality of the products, they rely on prior knowledge of the country from which the product comes and the $\mathrm{COO}$ then indicates the generally accepted quality of the product. There are many definitions of "quality", and it is a term that is defined by the consumer and his/her perception of the quality. This means that each consumer determines the quality of the product differently depending on their expectations and knowledge. What for one consumer may be a high-quality product, for another it may be a product of medium or low quality. From the marketing experts' point of view, quality means a term by which one product can be differentiated from another and thus create a competitive advantage.

The perception of product quality may depend on the economic development of the product's $\mathrm{COO}$, but also the consumer's $\mathrm{COO}$, and therefore the focus of this paper was pointed to the research of these issues. The aim was to investigate the perceptions of consumers coming from transitional and developed countries about the quality of products coming from developed and developing countries for three different product categories (three different levels of purchasing risk). For a product that has a high-level purchasing risk, the $\mathrm{COO}$ is extremely important when evaluating product quality and making a purchasing decision. This was shown by the results on general statements about products that have a high level of purchasing risk (there are no differences in the attitudes of respondents from the developed and transitional country) as well as statements related to a specific product. In the example of products with a medium-level purchasing risk, the conclusion is that the $\mathrm{COO}$ is important and that respondents have more positive attitudes towards the quality of such products coming from developed than from developing countries. Finally, for products with a low-level purchasing risk, the $\mathrm{COO}$ is not extremely important for evaluating product quality. Respondents have a positive attitude towards product quality for both, products that are originating from developed and developing countries, although attitudes towards the product which $\mathrm{COO}$ is developed country are more positive.

In conclusion, it can be stated that the perception of product quality depends on the COO development level of both - the consumer and the product. Respondents from developed countries had more positive attitudes about products from developed and developing countries compared to respondents from transitional countries. On the other hand, respondents from both developed and transitional countries have more positive attitudes towards products from a developed country, regardless of whether they are high-, medium- or low-level purchasing risk. Also, an important finding is that the $\mathrm{COO}$ is gaining in importance as the level of purchasing risk of the product increases.

The limitations of the research are related to the convenient sample and to selected products that represent different levels of purchasing risk and their pairing with $\mathrm{COO}$ of different development levels. At the same time, those limitations represent recommendations for future research. 


\section{LITERATURE}

1. Agarwal, S., \& Teas, R. K. (2000). The effects of extrinsic product cues on consumers' perception of quality, sacrifice and value. Journal of International Consumer Marketing, 28(2), 278-300.

2. Agyekum, C. K., Haifeng, H., \& Agyeiwaa, A. (2015). Consumer perception of product quality. Management and Economics Department, 12, 25-29.

3. Ahmed, S. A., \& d'Astous, A. (2004). Perceptions of countries as producers of consumer goods: A T-shirt study in China. Journal of Fashion Marketing and Management, 8(2), 187-200.

4. Ahmed, Z. U., Johnson, J. P., Yang, X., Fatt, C. K., Teng, H. S., \& Boon, L. C. (2004). Does country of origin matter for low-involvement products?. International Marketing Review, 21(1), 102-120.

5. Alden, D. L., Hoyer, W. D., \& Crowley, A. E. (1993). Country-Of-Origin, Perceived Risk and Evaluation Strategy. Advances in Consumer Research, 20, 678-683.

6. Amine, L., \& Shin, S-H. (2002). A comparison of consumer nationality as a determinant of COO preferences. Multinational Business Review, 10(1), 45-53.

7. Anastasiei, B., \& Chiosa, A. R. (2014.). Influence of country of origin on foreign product evaluation. Management and Marketing, 12(2), 219-225.

8. Anić, I. D. (2010). Attitudes and purchasing behavior of consumers in domestic and foreign food retailers in Croatia. Ekonomski fakultet Rijeka: Časopis za ekonomsku teoriju i praksu, 28(1), 113-133.

9. Apetrei A., \& Petrusca, C. (2010). Country-of-Origin Effect in International Trade. Timisoara Journal of Economics, 3(4), 271-276.

10. Banovic, M., Reinders, M. J., Claret, A., Guerrero, L., \& Krystallis, A. (2019). A cross-cultural perspective on impact of health and nutrition claims, country-of-origin and eco-label on consumer choice of new aquaculture products. Food Research International, 123, 36-47.

11. Bearden, W. O., \& Shimp, T. A. (1982). The Use of Extrinsic Cues to Facilitate Product Adoption. Journal of Marketing Research, 19, 229-239.

12. Bilkey, W. J., \& Nes, E. (1982). Country-of-Origin Effects on Product Evaluations. Journal of International Business Studies, 13(1), 89-99.

13. Biswas, K., \& Chowdhury, H.K. (2011). The effects of country-of-origin and price on consumer quality perceptions: A cognitive information processing perspective. International Journal of Management, 28(1), 111-126.

14. Brandao A., \& Duraes T. (2018). Content Marketing and Country-of-Origin Effect: The case of APICCAPS. International Journal of Marketing, Communication and New Media, 6(11), 74-94.

15. Brouthers, E. L. (2000). The influence of triad nations' environments on price-quality product strategies and MNC performance. Journal of International Business Studies, 31(1), 39-64. 
16. Bruwer, J., Fong, M., \& Saliba, A. (2013). Perceived risk, risk-reduction strategies (RRS) and consumption occasions Roles in the wine consumer's purchase decision. Asia Pacific Journal of Marketing and Logistics, 25(3), 369-390.

17. Cakici, N. M., \& Shukla, P. (2017). Country-of-origin misclassification awareness and consumers' behavioral intentions: Moderating roles of consumer affinity, animosity, and product knowledge. International Marketing Review, 34(3), 354-376.

18. Chao, P. (1998). Impact of Country-of-Origin Dimensions on Product Quality and Design Quality Perceptions. Journal of Business Research, 42, 1-6.

19. Chinen, K., Jun, M., \& Hampton, G. M. (2000). Product Quality, Market Presence, and Buying Behavior: Aggregate Images of Foreign Products in the US. Multinational Business Review, 8(1), 29-38.

20. Chun, K. S. (1992). Clothes: A question of quality. Business Korea, 10(5), 60-62.

21. Clifton, N. (2014). Towards a holistic understanding of country of origin effects? Branding of the region, branding from the region. Journal of Destination Marketing \& Management, 3(2), 122-132.

22. Cordell, V. (1991). Competitive context and price as moderators of country of origin preferences. Journal of the Academy of Marketing Science, 19(2), 123-128.

23. Dholakia, R. R., Zhao, M., \& Duan, J. (2020). The COO Construct: Methodological and Related Issues in a Globalized World. Journal of Global Marketing, 33(1), 3-17.

24. Diamantopoulos, A., Schlegelmilch, B., \& Palihawadana, D. (2011). The Relationship between Country-of-Origin Image and Brand Image as Drivers of Purchase Intentions: A Test of Alternative Perspectives. International Marketing Review, 28(5), 508524.

25. Dowling, G. R., \& Staelin, R. (1994). A Model of Perceived Risk and Intended Risk-Handling Activity. Journal of Consumer Research, 21(1), 119-134.

26. El Moussawel, O., \& Dekhili, S. (2018). Country-of-Origin Ecological Image: Dimensions of the Construct and their Impacts on Consumers' Evaluation of Eco-Products. Proceedings of the 2018 Academy of Marketing Science (AMS) World Marketing Congress (WMC). Eds: P. Rossi and N. Krey. Lisbon (Portugal), 27-29.6.2018. pp. 709710 .

27. Essoussi, L. H., \& Merunka, D. (2007). Consumers' product evaluations in emerging markets: Does country of design, country of manufacture, or brand image matter? International Marketing Review, 24(4), 409-426.

28. Garvin, D. A. (1987). Competing on the Eight Dimensions of Quality. Harvard Business Review, 65(6), 101-108.

29. Hamad, H., \& Schmitz, M. (2019). The Impact of Demographic Variables and Consumer Shopping Orientations on the Purchasing Preference for Different Product Categories in the Context of Online Grocery Shopping. Journal of Marketing and Consumer Research, 52, 21-32.

30. Huddleston, P., Good, L. K., \& Stoel, L. (2001). Consumer ethnocentrism, product necessity and Polish consumers' perceptions of quality. International Journal of Retail \& Distribution Management, 29(5), 236-246. 
31. Josiassen, A., \& Assaf, A. (2010). Country-of-origin contingencies: their joint influence on consumer behavior. Asia Pacific Journal of Marketing and Logistics, 22(3), 294-313.

32. Kalicharan, H. D. (2014). The Effect and Influence of Country-Of- Origin on Consumers' Perception of Product Quality and Purchasing Intentions. International Business and Economics Research Journal, 13(5), 897-902.

33. Karoui, S., \& Khemakhem, R. (2019). Consumer ethnocentrism in developing countries. European Research on Management and Business Economics, 25(2), 63-71.

34. Katsanis, P. L., \& Thakor, V. M. (1997). A model of brand and country effects on quality dimension; issues and implications. Journal of International Consumer Marketing, 9(3), 79-100.

35. Kim, R. (2008). Japanese consumers' use of extrinsic and intrinsic cues to mitigate risky food choices. International Journal of Consumers Studies, 32(1), 49-58.

36. Liefeld, J. (1993). Experiments on country-of-origin effects: review and meta-analysis of effect size. In: C. Papadopoulos \& L. Heslop (Eds.). Product-country images: Impact and role in international marketing (pp. 117-156). New York, NY: International Business Press.

37. Magier-Lakomy, E., \& Boguszewicz-Kreft, M. (2015). "Dimensions of the Country of Origin Effect and their Measurement". Gdansk School of Banking, Vol. 49, No. 3, pp. 125-134.

38. Milovan, A. M., Ardelean V. M., Sahour S. A., \& Jurca, F. C. (2019). The country of origin influence on the decision to buy whine. Ecoforum, 8(1), 39-71.

39. Nagashima, A. (1970). A comparison of Japanese and US attitudes towards foreign products. Journal of Marketing, 34(1), 68-74.

40. Papadopoulos, N., \& Heslop, L. (1993). Product and Country Images: Research and Strategy. New York, NY: The Haworth Press.

41. Parameswaran, R., \& Yaprak A. (1987). A cross-national comparison of consumer research measures. Journal of international business studies, 14, 35-49.

42. Parvin, S., Rahman, L. M., \& Uddin, J. (2013). Factors influencing importance of country of brand and country of manufacturing in consumer product evaluation. International Journal of Business and Management, 8(4), 65-74.

43. Piron, F. (2000). Consumers' perceptions of the country-of-origin effect on purchasing intentions of (in)conspicuous products. Journal of Consumer Marketing, 17(4), 308-321.

44. Ramsaran, R. R., \& Wibowo S. (2016). A Conceptual model for country-of-origin effect. Asia Pacific Journal of Advanced Business and Social Studies, 2(1), 96-116.

45. Roth, K. P., \& Diamantopoulos, A. (2009). Advancing the country image construct. Journal of Business Research, 62, 726-740.

46. Roth, M. S., \& Romeo, J. B. (1992). Matching Product Category and Country Image Perceptions: A Framework for Managing Country-of-Origin Effects. Journal of International Business Studies, 23(3), 477-497.

47. Samli, A. C. (1995). International Consumer Behavior: Its Impact on Marketing Strategy Development. Westport: Quorom Books. 
48. Schaefer, A. (1997). Consumer knowledge and country of origin effects. European Journal of Marketing, 31(1), 56-72.

49. Schooler, R. D. (1965). Product Bias in the Central American Common Market. Journal of Marketing Research, 2(4), 394-397.

50. Sharma, P. (2011). Country of origin effect in developed and emerging markets: Exploring the contrasting roles of materialism and value consciousness. Journal of International Business Studies, 42, 285-306.

51. Sharma, R. (2019). Consumer-Based Brand Equity: Does Country of Origin (COO) Matter to Generation Z Consumers?. South Asian Journal of Management, 26(1), 136150 .

52. Sohail, M. S. (2005). Malaysian consumers' evaluation of products made in Germany: the country-of-origin effect. Asia Pacific Journal of Marketing and Logistics, 17(1), 89-105.

53. Tigli, M., Pirtini, S., \& Can Erdem, Y. (2010). The Perceived Country of Origin Images in Turkey. International Business \& Economics Research Journal, 9(8), 127-133.

54. Touzani, M., Fatma, S., \& Meriem, L. M. (2015). Country-of-origin and emerging countries: revisiting a complex relationship. Qualitative Market Research: An International Journal, 18(1), 48-68.

55. Uddin, J., Parvin, S., \& Rahman, M. D. (2013). Factors influencing importance of country of brand and country of manufacturing in consumer product evaluation. International Journal of Business Management, 8(4), 65-74.

56. Urbonavičius, S., Dikčius, V., \& Navickaite, S. (2011). Country Image and Product Evaluations: Impact of a Personal Contact with a Country. Engineering Economics, 22(2), 214-220.

57. Verlegh, P. W., Steenkamp, J. E., \& Meulenberg, M. T. (2005). Country-of-Origin Effects in Consumer Processing of Advertising Claims. International Journal of Research in Marketing, 22(2), 127-139.

58. Wall, M., Liefeld, J., \& Heslop, L. A. (1991). Impact of Country-of-Origin Cues and Patriotic Appeals on Consumer Judgments: Covariance Analysis. Journal of the Academy of Marketing Science, 19, 105-111. 